\title{
Of (anti-)capitalism, countermovements, and social- democratic bedtime stories. A review of recent literature on Polanyi ${ }^{1}$
}

\author{
Moritz Müller (moritz.mueller@rub.de) \\ Ruhr-University Bochum, Germany
}

This paper reviews some newer and older books and articles that relate to Polanyi's analysis of capitalism, the countermovement, and his own perspective concerning the future after the possible end of market society.

Keywords: Polanyi, Capitalism, Marxism, Social Movements, Neoliberalism

\section{The continuing relevance of Polanyi's work}

When reading The Great Transformation, it "seems as if Polanyi is speaking directly to present day issues" (Stiglitz, 2001, vii). No wonder that his work is one of the most important theoretical references for scholars and activists, who aim to analyse, and, or at least embed capitalism (Aulenbacher et al., 2017). Frank Deppe (2012) has even named one of his latest books after Polanyi's opus magnum, implying that we - just as Polanyi - are living in times of a Great Transformation. Reason enough to discuss books and articles of contemporary thinkers that make use of Polanyi's arguments and figures to understand modern day shifts in capitalism, analyse social movements and search for possible countermovements capable of taming, embedding or even overthrowing capitalism. Rather than discussing the endless stream of literature referring to Polanyi one after the other, I set the discussion on the most interesting and politically relevant topics that can be found in almost every publication.

\section{Manifesto against capitalism or "social-democratic bedtime story"?}

In his biography of Polanyi, Gareth Dale $(2016 a, 9)$ presents him as a reformist socialist, who wanted to transform capitalism into socialism with parliamentary measures and "piecemeal alterations to existing institutions". Ironically, Polanyi's own life seems to be inseparably linked to that kind of social democracy in the $19^{\text {th }}$ and $20^{\text {th }}$ century. Polanyi was born in 1886, three years before the founding of the Second International, and died in 1964, five years after the Social Democratic Party of Germany officially rejected Marxism, and committed itself to the prosperity of capitalism.

Concerning the relation between Polanyi and Marx, Dale points out that Polanyi would have emphasized on "the contrast between non-market societies, in which economic relationships take immediate and personal forms, and market society, in which human

${ }^{1}$ I thank Ceren Tosun, Martin Seeliger and Sina Samadi for helpful advice concerning the expressions in this text as well as its structuring. 
relationships manifest themselves through the impersonal guise of exchange value, yielding, by way of commodity fetishism" (2016a, 137-138). In detail, Polanyi criticizes market societies for dividing the individual from its fellow human beings by processing economic transactions through the market. This would make it impossible for the individual to bear responsibility for his own actions. Furthermore, market society would lead to a destructive "institutional separation of the social spheres" into a political sphere, where responsibility would obtain, and an economic sphere, "steered by the price mechanism, in which it does not." For Polanyi, this would have been the main issue of his time (138). According to him, the proletariat was the representative of the general interest of society in its struggle against the consequences of the market.

Even though Polanyi's critique of marketization has some parallels to the Marxist critique of capitalist societies, it is based on morality rather than economic issues. Polanyi's concept of socialism is, as Dale (223) describes, based on some "core topics of 'socialist economics'": The reduction of the influence of market-transactions on society, the "ideological legacy" of this former dominant principle, the question of how economy might be reintegrated into society, and how science and technology can be democratically controlled. When it comes to the realization of this vision, Polanyi considers the state "as the pivotal agent of social progress" (271). According to this concept typical for "traditional social democracy", the state is neutral and can be seized by the organizations of the working class when they are strong enough. Subsequent to this, Polanyi's and social democracy's concept of socialism centers around the idea that private ownership should be replaced by public and/or cooperative ownership, together with the state's acceptance of its role as the responsible institution for social welfare. Polanyi has paid almost no attention to the various forms, in which the capitalist state itself, has become "systematically geared to the interests and imperatives of capital accumulation". These would be, for instance, enforcing contracts and punishing breaches, maintaining the "walls of property exclusion", the synchronization of the "media of commodity exchange", the regulation of labor's "regeneration, security, and circulation", tailoring the qualifications "to the needs of business" and investments in social infrastructure as well as ideologically legitimizing the process of capitalist accumulation (284). Dale then considers Polanyi's very abstract concept of society "an illusion". In the end, Dale sums up, Polanyi "failed to take stock of the fact that a system based on commodified labor power requires a supportive framework of non-commodified institutions, and that capitalism is capable of accommodating trade unionism, welfare measures, state intervention, and public ownership" (285).

When asked about the ongoing relevance of Polanyi's work, Dale highlights his "diagnosis of the corrupting consequences of the marketization of labor power and nature that gives his work a contemporary feel and explains its continued appeal" (282). Nevertheless, he states that the solutions offered by Polanyi appear out of date. That's why for Dale, Polanyi belongs to a bygone world, created by social democratic organizations at the end of the $19^{\text {th }}$ and the beginning of the $20^{\text {th }}$ century. His opus magnum, The Great Transformation could therefore, as Dale $(2016 \mathrm{~b}, 286)$ claims, "legitimately be read either as an anticapitalistic manifesto or as a social-democratic bedtime story: a provider of sweet dreams that help chastened idealists to rise in the morning, to get to work on the countermovement, more or less ruefully reinterpreted as a mission to improve, upholster, and repair the cogs of the market machine."

As Dale points out in another book $(2016 a, 4)$, the question whether Polanyi's work deserves a "hard" or a "soft" interpretation, is subject of a controversy that's still ongoing. The soft, "social-democratic mainstream"-position seeks to regulate capitalism while the market should "remain the dominant coordinating mechanism in modern economies, albeit complemented by redistributive and socially protective institutions". On the other hand, the hard interpretation of Polanyi's work would describe Polanyi as a "red-blooded 
socialist for whom the market could not remain and should never be the dominant mechanism of economic coordination" (5). Dale himself comes to the conclusion that the soft Polanyi might have the bigger fan-base while the hard Polanyi-supporters would better with the 'lyrics': He doubts that Polanyi would have actually believed that the market should stay "the dominant mechanism" and that Polanyi also would not have thought that the "pendular swing" would come automatically, as some kind of natural reflex of society against the market's assaults (6).

Similar to Dale, the German scholar Michael Brie $(2017,9)$ claims that Polanyi would not have had "hopes for a social protection movement on the basis of market society." For him, the market would have been "part of the problem and not the solution." Brie therefore describes approaches and interpretations that only view and Polanyi as an authority for an embedded capitalism, as "Polanyi faked" (10). Even though it would not have often been interpreted as such, The Great Transformation shows the "deeply grounded socialist background" of Polanyi's thought. The reason why the mainstream interpretation of his most famous work ignored those facts would be, as Brie (11) claims, that the last chapter of The Great Transformation would be "seldom dealt with" or at least "deprived of its socialist dimension." While Dale (2016b) postulates that Polanyi's work belongs to the bygone world of the $20^{\text {th }}$ century, Brie argues that The Great Transformation should not be understood as "a mere narration of $19^{\text {th }}$ and early $20^{\text {th }}$ century English and Western European history." Polanyi actually tried to convey that mankind has the "strategic choice" between socialism and fascism - a third option was not thought possible by Polanyi (Brie 2017: 11). While Dale (2016b, 282) claims that Polanyi belongs to a "lost world", Brie (2017, 14) reasons that Polanyi could "prove to be a travelling companion even today, who was waiting for us until the moment that the period moved closer to him." He even says that Polanyi might have been "ahead of us the whole time."

One of the reasons why Brie titled his work "a Socialist Thinker for Our Times" is that Polanyi would have "formulated a new radical concept of freedom, which includes both individual responsibility and the necessity of societal transformation." Here, Polanyi might have been led by the question "under what social conditions people can deal with freedoms in such a way that they do not harm others but support them in living their own lives" (16). While Dale (2016a) has already presented Polanyi's critique that people cannot really live their lives in responsibility for their actions as a major aspect of his general critique on capitalism, Brie goes further into detail, and shows that Polanyi tried to figure out how a society would have to be constructed "so that people could be put in a position to act completely responsibly" e.g. where people would be also responsible for the consequences of their actions (Brie, 2017, 16). He quotes Polanyi himself, who wrote that in such a society "no choice is possible, by allowing us to shoulder the finally inevitable burden of our responsibility for coercing and interfering with the lives of our fellows" (Polanyi, 1937, 16). This form of expression is very close to the vision of a communist society described by Marx and Engels $(1976,506)$, "in which the free development of each is the condition for the free development of all." Brie argues while using cars, airplanes, buying coffee and heating houses, nobody could "escape from this distressing confrontation with a life that cannot be personally controlled" and adds the verdict that such a life "makes people guilty" (Brie, 2017, 16). This situation has recently been picked up and elaborated by Lessenich (2016). Concerning Polanyi's vision of a socialist society, one of the most decisive aspects of Polanyi's critique on capitalism is the impossibility to live life with full responsibility for one's own actions and decisions. In a socialist society, people would not be controlled by the obscure processes of the market but can be masters of their own history once again a famous Marxist vision.

In the last part of his discussion of Polanyi's work, Brie tries to bring Polanyi into discussion with Nancy Fraser. She criticizes Polanyi's figure of the double movement because social 
movements such as the anti-imperialist, anti-war, feminist movement would not fit into the figure because they would neither push social protection nor marketization but emancipation. This is why Fraser has developed her own figure, the "triple movement", where emancipation has its place. With this concept, Fraser does not simply demand "greater inclusiveness" but instead wants to "capture the shifting relations among those three sets of political forces, whose projects intersect and collide." Each of the sides of the figure would be able to forge alliances with one of the others against the third (Fraser, 2013, 128129). According to her, there is "no going back to hierarchical, exclusionary, communitarian understandings of social protection", since their "innocence has been forever shattered, and justly so." In the end, she states that there could be "no protection without emancipation" (131).

Brie takes Frasers critique on the shortcomings of the double movement and turns it against her because the triple movement might include movements aiming at emancipation while completely ignoring the possibility that a countermovement might push for more domination and/or exploitation. PEGIDA, the AfD and similar movements and parties in other countries are examples for the rise of such "right-wing populist and neofascist forces". Therefore, Brie tries to complete the figure as a "quadruple movement" (Brie, $2017,20)$. He argues that for Polanyi, markets would have been "irrefutable [...] in complex societies" and, under the condition that they would be socially controlled, also productive. Consequently Brie reasons that processes of marketization could have "emancipatory or regressive and oppressive" effects, depending on the "social, economic and cultural "capital'" of the affected persons and groups. This leads him to propose a scheme "which measures the development of complex capital-dominated societies [...] neither as a pendulum motion between unleashing and taming of the markets nor by conceiving it through the addition of a third, an emancipatory, movement but by seeing the poles in a more general and fundamental way." While the vertical axis of his scheme consists of the two poles "Struggle for solidarity emancipation" and "Enforcement of exclusionary authoritarian tendencies", the poles on the horizontal axis are "Defense of inter-subjective rights of freedom" and "Access to the basic goods of a free life" (22). Of those axes, only the vertical one is the "either-or" type. The space between them is described as the "space of possible alternatives" filled by real movements (23).

Brie ends his chapter with the conclusion that there could be no "solidary emancipation without a new synthesis of the inter-subjective rights of freedom and access to the basic goods of a free life, the commons" (24). Finally, Brie formulates a political agenda for our times. He suggests: "We should work at counterposing to the alliance of neoliberalism and authoritarian social paternalism, which is now taking shape, an alliance of liberal socialists and thoroughly libertarian commonists." The "socio-cultural basis" finds Brie in a "solidary lower-middle alliance" with skilled personnel in the public services, wage-earners in services, industry and commerce as well as precariously employed as its "most important milieu". Realistically, Brie thinks that his project of a "transformative left" still has a long way to achieve a success (33).

However good Brie's and Fraser's approach may sound, one might ask - and this applies for Polanyi as well - how a society with markets might function without them taking control of social relations. Markets always go side by side with people in control of the market perhaps even using it to their own advantage. If the goods offered to them in exchange or if a person does not have any goods to exchange, this would probably lead to a situation, where the less powerful person will not be able to satisfy his or her needs. Also, Burawoy's critique on Polanyi seems to apply to Brie as well. Burawoy claims that Polanyi would have "believed in the power of ideas", what made him think that the in his time "discredited ideology of market fundamentalism could not take hold of our planet again" $(2010,301)$. When Polanyi and Brie both want the market to stay a mechanism for social transactions 
but in an embedded, socially controlled way, there is no guarantee that the forces of capital accumulation would not - as they have done in the pasts again and again - rise up and get the double movement back in business. Nevertheless, Brie offers some valuable insight into forgotten or neglected aspects of Polanyi's work and how it might be used today in a way the author himself would have been happy to experience it.

\section{Sociological Marxism almost without Marx?}

While Brie and Fraser are asking the question how a countermovement to neoliberal capitalism might look like, Michael Burawoy's contribution to the debate is characterized under the heading of two concepts - Sociological Marxism and Public Sociology. Both approaches are results of his critique of Polanyi as well as they are committed to Polanyi's political ambitions. Therefore, Public Sociology and sociological Marxism shall function as allies for a potential countermovement. Aulenbacher and Dörre concretize Burawoy's description and call his approach "sociological Marxism 'after Polanyi'" $(2015,10){ }^{2}$ What should Marxism after Polanyi be? Why do they describe Burawoy's approach in such a way?

In his opus magnum, Polanyi rejects some central aspects of Marxist theory that cast doubt on the term Marxism after Polanyi. In The Great Transformation, Polanyi claims for instance that class interests would only offer "a limited explanation of long-run movements in society", and states that the "fate of classes is more frequently determined by the needs of society than the fate of society is determined by the needs of classes". However, Polanyi never doubts the "essential role" that class interests play in social chance and even describes them as its "natural vehicle". Nevertheless, class interests could only prevail when representing "interests wider than their own" (Polanyi, 2001, 159). He claims that challenges are not to sectional interests but "to society as a whole"; its only society's response that would come through "groups, sections and classes" (160). At this point, Burawoy (2010: 301) criticizes Polanyi's concept of society as "nebulous and under theorized". When Polanyi tries to make his point clear by interpreting the protectionist movement after 1870, one might ask how the movement could have "simply responded to the needs of an industrial civilization with which market methods were unable to cope" (Polanyi, $2001,161)$, when this civilization and society is characterized by sectional and contradictory class interests. That's why Burawoy states that for Polanyi, "not exploitation but cultural devastation wrought by the market" would have been the driving forces behind Europe's $19^{\text {th }}$ century struggles $(2010,301)$. This is one of the major differences between Marx's critique on capitalism and Polanyi's.

Furthermore, Polanyi questions the "mistaken doctrine of the essentially economic nature of class interests" as such. He argues that "the motives of human individuals are only exceptionally determined by the needs of material want-satisfaction". In fact, he claims that "questions of social recognition" would be far more relevant to the behavior of a class than "[p]urely economic matters". Although recognition would often be expressed in form of the prize of labor, class interests would "most directly refer to standing and rank, to status and security" and by that be primarily social but not economic (Polanyi, 2001, 160). As Burawoy points out, this question has imminent political consequences when it comes to the question, around what kind of social conflicts a potential countermovement could gather. While traditional Marxism claims that this would still be a class conflict and classinterests, Polanyi's notion puts questions and aspects of recognition in its center: "While a Marxian project of labor internationalism" would try to bring together "working classes across factories, localities, nations, regions and the world, united by their common exploitation"; a "Polanyian scheme" of struggle would try to gather participants "on experience

\footnotetext{
${ }^{2}$ All translations from German texts into English were made by the author.
} 
of the market as distinct from experiences of production" (Burawoy, 2010, 306-307). Burawoy himself claims that commodification and not exploitation would be "the key experiences in our world today", because exploitation might be "essential to any analysis of capitalism", but could not be "experienced as such". While being on Polanyi's side in this case, he criticizes him for "rejecting Marxism" and creating a teleology of his own. The Great Transformation would reduce "a complex historical account to a single cycle: market devastation followed by counter-movement and regulated decommodification." Burawoy rejects this teleology and in return understands "the history of capitalism as a succession of great transformations and a complex intertwining of marketization and counter-movement, but with no definite end in sight" (307).

Burawoy further claims that there would be "powerful resonances between Marx and Polanyi" as well as "fundamental divergences between their commentaries" (301). He then criticizes Polanyi for refusing Marx's theory of accumulation because the processes of globalization and marketization could not be understood without a proper theory concerning the driving forces behind it (Burawoy, 2015, 44-45). This is important because it is one of the major reasons of Burawoy's critique on Polanyi. The central aspect is the false optimism in Polanyi's work. Since Polanyi didn't see the powers of the accumulation of capital as a driving force of development, but ever more so "believed in the power of ideas", he was able to think that the in his time "discredited ideology of market fundamentalism could not take hold of our planet again" (Burawoy 2010, 301). Other than Polanyi, Burawoy emphasizes "the imperatives of capitalist accumulation that lie behind the resurgence of markets". Another point of critique is centered around the fact that Polanyi would have, in his theory on the countermovement, "too easily reduced state to society, missing their complex interplay" (302).

While Burawoy criticizes Polanyi for rejecting major aspects and advantages of Marxist theory, he himself does almost not refer to specifics of Marxism at all - but ever more so to Polanyi (Neidhardt, 2017). As Dale shows, the focus of Burawoy's analysis does not lie "on production or exploitation". This leads him to criticize Burawoy for divesting Marxism "of its core theses" which would make his approach turn out to be "an essentially Polanyian research programme" (Dale, 2016b, 35). What does Burawoy himself say concerning this verdict? He criticizes so-called "neo-Marxists" for treating Marxism "as a supermarket", from which they think they could "take what pleases them and leave behind what does not." On the contrary, his own approach would respect Marxism as "a living tradition that enjoys renewal and reconstruction". This leads him to the conclusion that Marxism would have to change at the same time the world does (Burawoy, 2013, 35). Regardless of the changes and developments, Marxism would be defined by four "foundational claims": Historical materialism, the "premises of history", "notions of human nature" and "the relation of theory and practice". The trunk of it all would be the Marxist theory of capitalism (36). Sociological Marxism, the variety of Marxism which Burawoy favors, is then described as "based on an expanding and self-regulating civil society" while its predecessors would have been "the projection of an economic utopia" (classical Marxism), or "based on state regulation" (Soviet Marxism, Third World Marxism and Western Marxism) (37).

In his attempt to keep Marxism up to date, Burawoy breaks with the "Marxist claim that production provides the foundation of opposition to capitalism." For Burawoy - just like Polanyi - the market and not production is "the most salient experience today." To justify his thesis, he argues that consent to capitalism would be organized in the sphere of production while exploitation would, in times of a numerous surplus labor-population all over the globe, become more and more of a privilege. To not be misunderstood, Burawoy emphasizes that exploitation would still play a huge role in the process of capitalist accumulation but would not be experienced as such by the exploited laborers. While Marxist theory claims that the "experience of the market appears as the 'fetishism of the 
commodities'", Burawoy argues that it would be more than just a fetishism, since it affects the existence of humans in multiple dimensions (37). This critique leads Burawoy to a reconstruction of Polanyi, because he would, as Burawoy states, have a better understanding of the positive and negative consequences of markets on society but on the other hand, he would not take "the logic of capitalism seriously" (38).

Concerning classical Marxism, Burawoy claims that it "suffered from three fatal flaws": A wrong theory of class struggle, because instead of organizing against capitalism, the working class would often organize to gain concessions within capitalism. The second "flaw" would be an underdeveloped theory of the state since the state would be "organized to defend capitalism against capitalists as well as workers." It would recognize and enforce "the material interests of workers, in a limited but crucial way, trough trade unions and parties, but it also regulates relations among capitalists so that competition does not destroy capitalism" (43). Here Burawoy is wrong: In his text Anti-Dühring, for example, Friedrich Engels has described the state as the "ideal personification of the total national capital", which - from time to time - also engages against the interests of single capitalists to keep the general process of capitalist accumulation going (Engels, 1978, 265). This makes Marx's and Engels' notion of the state not that different from Burawoy's own. According to Polanyi's theory of the state, even though Burawoy describes it as more developed than the Marxist theory, the state "is conceived not primarily as a means of political oppression or instrument of bourgeois rule but in the mainstream sense: as the institution trough which a community of citizens fashions itself as a collective subject with a common will, as an instrument for the self-regulation of society" (Dale, 2016b, 53). By following Polanyi's notion of the state, instead of the Marxist's, Burawoy does not help Marxism to get to a more adequate, contemporary understanding of the state but falls back behind the Marxist state of the discussion.

What are the political perspectives of Burawoy's sociological Marxism? While the "first wave of Marxism" would be "characterized by the contradiction between capital and labor" (Burawoy, 2013, 44), the third wave would "not emerge through some catastrophic break with the past [...] nor through state-sponsored socialism from above, but through the molecular transformation of civil society." It would take "real utopias", "small-scale visions of alternatives such as cooperatives, participatory budgeting and universal income grants" to challenge both "market tyranny" and "state regulation" (47-48). The job of sociological Marxism would then be "to elaborate the concrete utopias found in embryonic forms of throughout the world" and to keep alive "the idea of an alternative to capitalism, an alternative that does not abolish markets or states but subjugates them to the collective selforganisation of society" (48). Again, one might ask, what exactly this vision has to do with Marxism. When Dale (2016b, 35) claims that Burawoy's research program would be "essentially Polanyian", the same can be said about the political agenda of his sociological Marxism.

\section{The project of Public Sociology}

The Polanyian research agenda of Burawoy has direct consequences on his concepts of sociological Marxism and Public Sociology (Burawoy, 2005). The latter project has found some followers in German sociology over the last years (Aulenbacher et al., 2017; Aulenbacher \& Dörre, 2015; Dörre, 2017). Burawoy tries to "construct a synthesis of Polanyian theory with Gramsci's thoughts on hegemony, reinterpreted as an argument for the formation of lasting multi-class coalitions" (Dale, 2010, 241). Dale criticizes both Burawoy and Polanyi for promoting a theory where "society" is defined as the plain "antithesis of the free market" that would mediate "between state and economy" and provide a common ground for the rise of the "solidarity among all classes" (242). This critique becomes clear 
when examining the following appeal of Burawoy: "Sociology lives and dies with society. When society is threatened so is sociology" $(2007,366)$.

Burawoy's approach for a Public Sociology has first been presented in 2005. Originating from the thesis of a certain "division of sociological labor", he describes Public Sociology as one variety of sociology near policy sociology, professional sociology and critical sociology (Burawoy, 2005, 9). He further states that he does not propagate a strict separation between the four types and rather wishes for "an organic solidarity, in which each type of sociology derives energy, meaning, and imagination from its connection to the others". At the heart of every form of sociology, its "professional component" should remain because without such, neither of them could exist (15).

The following notion, where he describes the "Sociologist as partisan", clearly presents Burawoy as an heir of Polanyi. In a very schematic distinction, he differentiates between the standpoints and tasks of economy, political science and sociology: "If the standpoint of economics is the market and its expansion, and the standpoint of political science is the state and the guarantee of political stability, then the standpoint of sociology is civil society and the defense of the social. In times of market tyranny and state despotism, sociologyand in particular its public face-defends the interests of humanity" (25). He further argues that the different disciplines within the social sciences would "represent different and opposed interests", especially "interests in the preservation of the grounds upon which their knowledge stands." For economics, that would be the "existence of markets with an interest in their expansion", while political science would depend "on the state with an interest in political stability". Sociology, then, would depend "on civil society with an interest in the expansion of the social." Accordingly, Burawoy defines civil society as "movements and publics that were outside both state and economy - political parties, trade unions, education, communities of faith, print media and a variety of voluntary organizations." He adds the thought that "[w] hen civil society flourishes [...] so does sociology" (24).

Facing a "third wave of marketization [...] sweeping the world, destroying the ramparts laboriously erected to defend society against the first and second waves of the previous two centuries" (Burawoy, 2007, 356), sociologists would have the choice to "engage directly with society before it disappears". This choice would be Public Sociology. Because they are identified as the driving forces behind the third wave, Burawoy claims that Public Sociology must not "collaborate with market and state" (357).

This approach of has been met with sympathy by some of the most influential sociologists in Germany. They, just like Burawoy, want a critical sociology to seek contact to social movements and countermovements. In their approach, Public Sociology should play a part in stopping the "decay of civil society and its organization" while helping to create and stabilize counter-public (Aulenbacher et al., 2017, 27). To do this, Aulenbacher and Dörre (2015: 10) demand that sociology should leave the "ivory tower" and help constitute a "global democratic civil society beyond core state and the market". Klaus Dörre $(2017,34)$ goes more into detail and states that we would be witnesses of another Great Transformation, characterized by forms of "post-growth"-capitalism in the metropolises that would more and more react in an authoritarian manner to systematic instabilities. In this situation, Public Sociology could help "generate knowledge about the possibilities and difficulties of social change that is indispensable for processes of social transformation" (3536). He then identifies trade unions, politics and cooperatives as potential allies for this project. In the end, he - similar to Brie - wants to develop "neo-socialist" alternatives that would subject the systematic growth drivers of capitalist societies to forms of democratic control by civil society" (34).

Other German scholars are skeptical about how Public Sociology might function as a powerful ally to social movements and countermovements. As Müller $(2017,114)$ claims, Public Sociology - as shaped by Burawoy and his German supporters - would "talk pretty big". 
Müller doubts that sociology could again be able to play the role it used to play during the 1960s and 1970s, when it acted like and was by some also perceived as the leading science that could "tell society what to think and what to feel". Müller argues that sociology would be a "voice among many but not a dominant one" and claims that it would be very unlikely that this would change (115). Similar to Müller, also Neidhardt $(2017,306)$ is skeptical when it comes to the idea that a "conglomerate of somehow oppositional players" within civil society could turn out to be a "historical subject of social change". With reference to the history of social movements and social change he then argues that there would be plenty of examples for forces of social transformation that used to be fragmented and bound together lose in the beginning. But instead of learning from such examples, Neidhardt blames "Burawoy and his followers" of ignoring the results of research on social movements. Playing some kind of advisor for the public sociologists, he recommends the theories of social movement-studies as a possible guidance. Even harder is his critique for the public sociologists' refusal to cooperate with forces of market and state because he claims that this would lead to a "systematical renunciation of politics" and weaken Public Sociology in pursuing its goal to help groups within civil society to progress (308). Despite this constructive critic, Neidhardt rejects the concept of Public Sociology as shaped by Burawoy and his colleagues. He argues that it would hinder "sociology's inter- and intra-disciplinary orientation" and criticizes it for claiming to represent the interests and standpoint of civil society while accusing political science and economics to represent the interests and standpoints of the state and the market. This analysis would not only be blurred but also tear apart the interdisciplinary context necessary for every sociology that claims to be dedicated to social change (308). The same judgement is made concerning Burawoys varieties of sociology that would be a "key element" of his concept and express Burawoys contempt for the other existing forms (309). In the end, Neidhardt comes to the conclusion that Public Sociology would be "less of a theory and more of a declaration of intent". The concept as developed by Burawoy would then function as a "compensation for theory" (310). Even though he does not doubt the integrity of Burawoy and his followers, Neidhardt identifies "ambiguities and contradictions" within their program. These factors and critique would pose a risk for Public Sociology in terms of its scientific respectability (313314). In conclusion, Neidhardt claims that it would not always be possible to have "knowledge and movement" at the same time (314). For him, Public Sociology is not able to fulfill its own promises and instead lead to a "de-politicization" and "de-economization" of sociology. Finally, civil society, Public Sociology's object of desire, would not have much to expect from its admirers.

\section{Global Labor Studies}

Another section of sociology, Global Labor Studies, can also be portrayed as Polanyi's heir. Burawoy criticizes they would all share four "elements of false optimism" that could also be found in the work of Polanyi himself: The faith in the "power of ideas" while ignoring the "imperatives of capitalist accumulation", an "under-theorized notion of society", believing that it would more or less automatically "summon up its own defense in the fact of a market onslaught" and, finally, reducing "state to society" without acknowledging their far more complex relation (Burawoy, 2010, 301-302).

But is this critique precise? The authors of the book Grounding Globalization (Webster, Lambert \& Bezuidenhout, 2008) are in the focus of Burawoy's critique, who claims that their purpose would without a doubt be important, but nonetheless their "political desires" would "overwhelm their analysis when they claim to see in their case studies movements - Marxian and Polanyian - thwarting the tide of neoliberalism." In Grounding Globalization, the countermovement would become "a mirage, a fantasy" that would disavow the authors "intention to ground globalization" (Burawoy, 2010, 304). Burawoy further 
accuses the authors of following a "Polaniyan teleology", since they would homogenize "a malignant past" and then invert it "into a radiant future." This would not only result in a "false homogenization of history but also of geography" in terms of a "dichotomous northsouth distinction". Eventually, their "flight of fancy into labor internationalism and utopian society" would make them dream "a Marxian dream" as well as a "Polanyian dream" (305). The authors themselves are, unlike Burawoy's suggestions, quite critical of Polanyi and argue that there would be "major gaps" in his theory of the double movement, especially "his undertheorizing of how a counter movement is constructed." They even state "the absence of a theory of social movements" in Polanyi's work and want to "identify the processes trough which transnational activism emerges". Although Burawoy blames them for following a teleology just like Polanyi, their innovative approach is based on the critique that global labor studies would have almost at all ignored "the impact of global restructuring on the non-working life of workers". The assumption of the authors is that an analysis of the workplace is not enough, and that scholars "need to examine workers as a totality, workers in society", because changes in the employment relationship would directly impact "worker's households and the communities of which they are part" of (Webster et al., 2008: $x)$.

The authors emphasize the topicality of Polanyi's theory, since he would be "profoundly shaped by moral concern over the psychological, social and ecological destructiveness of unregulated markets." This assessment would also resonate in our times, "because such a relentless drive towards a market orientation" would lie "at the very heart of the contemporary globalization project" and lead to the consequence that "market-driven politics dominates nations across the globe". Therefore, political discourses center "on the language of the market: individualism, competitiveness, flexibility, downsizing, outsourcing and casualization" (4).

In their book, the authors identify "five areas of under-theorization" or "theoretical shortcomings" in Polanyi's work (5). The first, the "society problem" would be rooted in the fact that Polanyi doesn't have a clear concept of what society actually is. Like Burawoy, they argue that "society occupies a certain institutional space between the state and the economy." But at the same time they claim that Polanyi wouldn't be able to describe how institutions of the society are related to the state and the economy. Moreover, they claim that the "boundaries between society, the state and markets may be analytically distinct, but in reality these boundaries are not fixed and tend to shift over time" (6). Another problem they determined in Polanyi's theory is the "spontaneity problem". Webster et al. (8) argue that countermovements are not spontaneous reactions to processes of marketization but have to be organized. Because Polanyi does not provide any help here, they turn to social movement theory, because it offers "an understanding of the structural conditions, political opportunities and repertoires that movements draw on, and how resources are mobilized when social movements engage in contentious politics." This approach would show that countermovements are not only "reflex against globalization" but also "shaped by changes in the opportunity structures of international politics." The third problem they identify is the "labor movement problem" which leads to the question whether this movement can be part of a countermovement. The authors believe that labor studies should not only analyze reasons for the decline of the movement in the past but "explore the contradictions that may create the opportunity for a counter-movement to emerge" (10). For this, the "power problem" (11), they turn to Beverly Silver (2012), her critique of Polanyi and her theory of power. When it comes to the "scale problem", Webster et al. $(2008,14-15)$ argue that while Polanyi would have "worked within the parameters of the nation state, which he saw as analytically sufficient and the arena within which countermovements evolved", a "more sophisticated understanding of how markets, governance 
and social responses are embedded in place, and how landscapes of spaces and scale form the basis for contestation".

What are the findings of their study in Australia, South Africa and South Korea? In all three countries, the authors state that market ideology has pushed politics of privatization, for example of the supply with water and electricity, with a huge impact on the living conditions of major parts of the inhabitants of the cities where they did their research. For them, the privatization is the result of "market-driven politics characterized by the penetration of corporate into the activities of the states, which erodes democracy, citizenship and the public interest" (78-79). When corporations start controlling "key areas of human need", they reduce social relations "to the status of commodity relations where everything is measured by the market" (103). How do people react to such developments? In their case studies, they find two different responses: A retreat from the market and an adaption to it. While in Orange/Australia, unemployed persons rested on welfare and developed rightwing attitudes, workers in Ezakheni/South Africa stopped trying to be wage-laborers and concentrated on the resources they had in their households as potential sources of income. In Changwon/South Korea, workers started working harder and longer when they were put under pressure by their employers (157). On the political level, the researchers found different responses to the threats of the market as well. People founded new parties, unions forged transnational alliances with workers from their company who worked in other countries and organized irregular workers, and pushed the state to put a quota on imported products. Even though the authors report "innovative attempts by local community organizations and the trade union movement to search for security and ways of protecting society against growing commoditization", they also claim that the reported responses would "lack an overall vision of an alternative response to the challenge of globalization" (158). If the social movements really wanted to challenge the power of the market, they would need "to involve some notion of an alternative to current power relationships" (159).

Just like Brie, Burawoy and the other public sociologists, Webster et al. follow a political agenda and make more or less detailed suggestions how the problems are described and could be dealt with on a multi-level scale. They talk about "six key areas that inquire imagination and hard work if a democratic alternative is to emerge" (213). Based on the assumption that the destruction of the environment is "the central social issue of the twentyfirst century", they demand the introduction of "a new economic logic that reconnects social needs and nature." While they claim "the right to certain basic needs such as food, shelter and clothing", they refuse to accept a right to "those wants that are constantly manufactured and manipulated by the market" (217-218). Here, one might ask, what the society the authors want to live in, should look like - aren't most of our wants and needs a social construct? Where does the manipulation begin? Taken by their word, one might believe that the authors want to live in a society where only our most essential needs are satisfied while the rest is a sign of decadency.

When they distinguish between basic needs and such that would be manufactured and manipulated, the authors use a scheme of argumentation similar to Polanyi's distinction between natural and fictitious commodities. For Polanyi, commodities are "objects produced for sale on the market" $(2001,75)$. Labor, money, and land, three very important commodities in capitalist societies, would not be "produced for sale", which is why their description as commodities would be "entirely fictitious" (76). This leads Polanyi to the political demand that the fictitious commodities should not be subordinated to market mechanism since this would lead to the subordination of "the substance of society itself to the laws of the market" (75). With commodities that are not fictitious, Polanyi did not see such a problem. Polanyi's notion of the commodity is another example of his rejection of central aspects of Marxist theory. While for Marx, every commodity is fictitious because 
a good becomes a commodity in the very moment where it is sold or exchanged on a market and therefore a "social relation" (Dale, 2010, 77), Polanyi makes a "moral distinction" (Dale, 2016b, 52). With regard to Webster et al.'s distinction between natural needs and manufactured needs, one might argue that they have a fetishized notion of human needs just as Polanyi has a fetishized notion of commodities. Instead of pointing out that there are good and bad needs, a more realistic perspective would emphasize the fact that - besides the need to sleep, eat and seek shelter from climate etc. -, all needs are socially constructed and the result of the development of human societies. Thus, the critique would focus less on needs, but more on the marketization and commoditization of the means to fulfill those needs.

Burawoy's critique that Webster et al. would underestimate the power of capitalist accumulation is justified when they propose a "new vision" of work. New Technologies could be used to create a better work-life-balance for the employed and lead to reduced working hours and a "breaking of the work-income nexus". Furthermore, people who earn minimum wages and/or work in the informal sector could benefit from "a social floor of minimum income and social security benefits." Such a policy of "levelling-up" would strengthen the "market-based bargaining power of working people" and even "make poverty history" - at least that's what the authors claim $(2008,219)$. Given the framework of a capitalist society, such a scenario is extremely unlikely. Of course, all those measures could be undertaken, on a very abstract level, to create a better life for everybody. When bearing in mind that capitalist societies necessarily produce poverty and exclusion via the market and are characterized by asymmetrical power relations and class interests, such a scenario doesn't seem feasible within a market society.

The authors correctly point out that to realize their visions, it would be necessary to "socially embed and regulate the corporation" as the form of organization that "lies at the center of market-driven politics". But the solution offered by them is revamping corporate law and letting the state "ensure that the corporation is harnessed to meet the needs of society" (219). It is the very state that has in the last decades proven to be so "notoriously hostile to labor" (Burawoy, 2010, 304) that Webster et al. $(2008,221)$ present as the institution that shall embed the market and help to regulate "trade in a way that brings society back into the economic equation". This very abstract expression is combined with the demand to transform institutions like the World Trade Organization into institutions which "represent the interests of society" - whatever those interests may be. More convincing is their argument that their approach would have to require an international dimension and "link the global to the local" since any "single nation-state that attempts to move in the direction of an alternative in any or all of the key areas [...] would come up against the power of global corporations and global finance" (222). This is the most realistic vision they design, because it can directly be related to the experience of movements and parties like Syriza in Greece, which started to challenge the neoliberal regime of austerity in the European Union and, after some time, ended up meeting more or less all demands of the forces behind austerity.

All in all, Webster et al. prove almost all critique from Burawoy right. Their approach can be described as typical example of Global Labor Studies that Seeliger has described as "programmatically optimistic". The will of Webster et al. goes as far as letting their political agenda sometimes lose contact with reality and the structural conditions for the agency of the movements they do research on. When they claim that attempts to break free from neoliberalism at the national level would be totally insufficient, Seeliger replies that the "idea that differences between the national and (macro-)regional settings allow for a general political mobilization in the sense of an international working class can, [...] by no means be treated as factual reality and rather - at least to date - constitutes no more than a programmatic hypothesis" $(2018,3)$. Many aspects of Grounding Globalization, one 
might summarize, show that for the authors, desire is the father of thought, research agenda and the empirical findings.

\section{References}

Aulenbacher, B., \& Dörre, K. (2015). Michael Burawoys Soziologie - eine kapitalismus- und wissenschaftskritische Herausfordrung. In M. Burawoy, Public Sociology. Öffentliche Soziologie gegen Marktfundamentalismus und globale Ungleichheit. Herausgegeben von Brigitte Aulenbacher und Klaus Dörre mit einem Nachwort von Hans-Jürgen Urban (9-22). Weinheim, \& Basel: Beltz Juventa.

Aulenbacher, B., Burawoy, M., Dörre, K., \& Sittel, J. (2017). Zur Einführung: Soziologie und Öffentlichkeit im Krisendiskurs. In B. Aulenbacher, M. Burawoy, K. Dörre \& J. Sittel (Eds.), Öffentliche Soziologie. Wissenschaft im Dialog mit der Gesellschaft (11-30). Frankfurt a.M.: Campus.

Brie, M. (2017). Karl Polanyi in dialogue. A socialist thinker for our times. Retrieved from https://www.researchgate.net/profile/Michael_Brie/publication/319799191_Karl_Polan yi_in_Dialogue_A_Socialist_Thinker_for_Our_Times/links/59bcba57aca272aff2d4c08d/K arl-Polanyi-in-Dialogue-A-Socialist-Thinker-for-Our-Times.pdf

Burawoy, M. (2005). For Public Sociology. American Sociological Review, 70(1), 4-28. doi: 10.1177/000312240507000102

Burawoy, M. (2007). Public Sociology vs. the market. Socio-Economic Review, 5(2), 356367. doi: $10.1093 / \mathrm{ser} / \mathrm{mwl} 031$

Burawoy, M. (2010). From Polanyi to Pollyanna: The false optimism of Global Labor Studies. Global Labor Journal, 1(2), 301-313. doi: 10.15173/glj.v1i2.1079

Burawoy, M. (2013). Marxism after Polanyi. In Williams, K., \& Satgar, V. (Eds.), Marxisms in the $21^{\text {st }}$ Century. Crisis, Critique \& Struggle (34-52). Johannesburg: South Africa: WITS University Press.

Burawoy, M. (2015). Facing an unequal world. Current Sociology, 63(1), 5-34. doi: 10.1177/0011392114564091

Dale, G. (2010). Karl Polanyi. The limits of the market. Oxford: Polity Press.

Dale, G. (2016a). Karl Polanyi. A life on the left. New York: Columbia University Press.

Dale, G. (2016b). Reconstructing Polanyi. Excavation and critique. London: Pluto Press.

Deppe, F. (2012). Gewerkschaften in der Großen Transformation. Von den 1970er Jahren bis heute - Eine Einführung. Köln: PapyRossa.

Dörre, K. (2017). Nach dem schnellen Wachstum. Große Transformation und öffentliche Soziologie. In B. Aulenbacher, M. Burawoy, K. Dörre, \& J. Sittel (Eds.), Öffentliche Soziologie. Wissenschaft im Dialog mit der Gesellschaft (33-67). Frankfurt a.M.: Campus. 
Engels, F. (1978). Anti-Dühring. Marx and Engels collected works, volume 25. Moscow: Progress Publishers.

Fraser, N. (2013). A triple movement? Parsing the politics of crisis after polanyi. New Left Review, 54(81), 119-132. doi: 0.1007/978-3-318-45590-7_3

Lessenich, S. (2016). Neben uns die Sintflut. Die Externalisierungsgesellschaft und ihr Preis. Berlin: Hanser Berlin.

Marx, K., \& Engels, F. (1976). Manifesto of the Communist Party. In Marx Engels Collected Works, vol. 6 (477-519). New York: International Publishers.

Müller, H. P. (2017). Die Grenzen der Soziologie. In B. Aulenbacher, M. Burawoy, K. Dörre \& J. Sittel (Eds.), Öffentliche Soziologie. Wissenschaft im Dialog mit der Gesellschaft (113118). Frankfurt a.M.: Campus.

Neidhardt, F. (2017). "Public Sociology" - Burawoy-Hype und linkes Projekt. Berliner Journal für Soziologie, 27(2), 303-317. doi: 10.1007/s11609-017-0345-3

Polanyi, K. (1937). Statements from christian left training week-ends. Retrieved from http://hdl.handle.net/10694/764

Polanyi, K. (2001). The Great Transformation. The political and economic origins of our time. Boston: Beacon Press.

Seeliger, M. (2018). Ambivalences of the countermovement. A proposal on how to study international trade unionism. Transnational Social Review, 8(1), 1-15. doi: 10.1080/21931674.2018.1452491

Silver, B. (2003). Forces of labor. Workers' movements and globalization since 1870 (Cambridge Studies in Comparative Politics). Cambridge: Cambridge University Press.

Stiglitz, J. E. (2001). Foreword. In K. Polanyi, The Great Transformation. The Political and Economic Origins of Our Time (vii-vvii). Boston: Beacon Press.

Webster, E., Lambert, R., \& Bezuidenhout, A. (2008). Grounding globalization. Labour in the age of insecurity. Malden: Blackwell. 